\title{
OTOACOUSTIC EMISSIONS FOR EVALUATING THE LOW-FREQUENCY HEARING OF PATIENTS CONSIDERED FOR PARTIAL DEAFNESS TREATMENT
}

\author{
W. Wiktor Jedrzejczak ${ }^{1,2}$, Krzysztof Kochanek ${ }^{1,2}$, Lech Sliwa ${ }^{1,2}$, Bartosz Trzaskowski, ${ }^{1,2}$, \\ Edyta Pilka ${ }^{1,2}$, Piotr H. Skarzynski ${ }^{1,3}$, Henryk Skarzynski ${ }^{1,2}$
}

${ }^{1}$ Institute of Physiology and Pathology of Hearing, ul. Zgrupowania AK “Kampinos” 1, 01-943 Warszawa, Poland
${ }^{2}$ World Hearing Center, ul. Mokra 17, Kajetany 05-830 Nadarzyn, Poland
${ }^{3}$ Institute of Sensory Organs, ul. Mokra 1, Kajetany 05-830 Nadarzyn, Poland

Corresponding author: W. Wiktor Jedrzejczak, Institute of Physiology and Pathology of Hearing, ul. Zgrupowania AK “Kampinos” 1, 01-943 Warszawa, Poland, e-mail: w.jedrzejczak@ifps.org.pl

\begin{abstract}
Background: In the present study otoacoustic emissions (OAEs) were used to evaluate the hearing of partial deafness subjects who had normal hearing up to $0.5 \mathrm{kHz}$ and severe hearing loss above that frequency. The purpose of the study was to detect OAEs at $0.5 \mathrm{kHz}$ and determine whether broad-band or band-limited values of OAE parameters were better for distinguishing ears with OAEs from those without.
\end{abstract}

\begin{abstract}
Material and Methods: The study group consisted of 15 subjects with high-frequency hearing loss above $0.5 \mathrm{kHz}$. For reference, a group of 15 subjects with severe to profound sensorineural hearing loss over the whole of the $0.125-8 \mathrm{kHz}$ range was used. In both groups, click-evoked OAEs (CEOAEs) and tone burst-evoked OAEs (TBOAEs) of 1 or $0.5 \mathrm{kHz}$ were evaluated using a reproducibility parameter, taking into consideration broad-band, octave, and half-octave band values.
\end{abstract}

Results: In the study group the best results were obtained by using $0.5 \mathrm{kHz}$ TBOAEs. Clicks and $1 \mathrm{kHz}$ tone bursts generally did not produce a response at $0.5 \mathrm{kHz}$. TBOAEs at $0.5 \mathrm{kHz}$ enabled the separation of partially deaf ears from ears with severe hearing impairment. Half-octave band filtering yielded the best results; however, it was only slightly better than broadband and octave band filtering.

Conclusions: The results of the study indicate that the $0.5 \mathrm{kHz}$ TBOAE is a better stimulus than CEOAE and $1 \mathrm{kHz}$ TBOAE when cochlear function at low frequency needs to be tested. The half-octave band seems the best choice in order to get frequency-specific information. However the results should be treated with caution since the studied groups were relatively small.

Key words: otoacoustic emissions $\bullet$ partial deafness treatment $\bullet$ reproducibility

\section{LAS EMISIONES OTOACÚSTICAS PARA LA EVALUACIÓN DE LA AUDICIÓN DE BAJA FRECUENCIA EN PACIENTES CONSIDERADOS PARA EL TRATAMIENTO DE LA SORDERA PARCIAL}

\section{Resumen}

Antecedentes: En el presente estudio las emisiones otoacústicas (EOA) se utilizaron para evaluar la audición de los pacientes con sordera parcial que tenían audición normal hasta $0,5 \mathrm{kHz}$ y sufrían de pérdida de audición severa por encima de esa frecuencia. El propósito del estudio fue detectar las emisiones otoacústicas a $0,5 \mathrm{kHz}$ y determinar si los valores de banda ancha o de banda limitada de los parámetros de emisiones otoacústicas son mejores para los oídos distintivos con las emisiones otoacústicas que para los que no las tienen.

Materiales y métodos: Se analiza un grupo de 15 pacientes con pérdida de audición de alta frecuencia por encima de $0,5 \mathrm{kHz}$. Para referencia, se utilizó un grupo de 15 pacientes con pérdida de audición neurosensorial severa a profunda sobre la totalidad de la gama $0.125-8 \mathrm{kHz}$. En ambos grupos, las emisiones otoacústicas evocadas por click (CEOAEs) y las emisiones otoacústicas evocadas por tono (TBOAEs) de 1 o $0,5 \mathrm{kHz}$ se evaluaron utilizando un parámetro de la reproducibilidad, teniendo en cuenta los valores de banda ancha, de octava y de media octava.

Resultados: En el grupo de estudio los mejores resultados se obtuvieron mediante el uso de TBOAEs de 0,5 kHz. Los clics y las ráfagas de tono de $1 \mathrm{kHz}$ en general no produjeron respuesta a $0,5 \mathrm{kHz}$. TBOAEs a $0,5 \mathrm{kHz}$ permitieron la separación de 
Jedrzejczak W.W. et al. - Otoacoustic emissions for evaluating the low-frequency hearing of partial deafness patients

los oídos con sordura parcial de los oídos con hipoacusia severa. El filtrado de la banda de media octava obtuvo los mejores resultados, sin embargo, fue sólo ligeramente mejor que el filtrado de banda ancha y de banda de octavas.

Conclusiones: Los resultados del estudio indican que el TBOAE de 0,5 kHz es un estímulo mejor que CEOAE y TBOAE de $1 \mathrm{kHz}$ cuando la función coclear a baja frecuencia tiene que ser probada. La banda de medias octavas parece la mejor opción para obtener la información de frecuencia específica. Sin embargo, los resultados deben ser tratados con precaución, ya que los grupos estudiados fueron relativamente pequeños.

Palabras clave: emisiones otoacústicas • tratamiento de la sordera parcial • reproducibilidad

\section{OTO-ÉMISSIONS ACOUSTIQUES DANS L'ÉVALUATION DE L'AUDITION EN BASSES FRÉQUENCES DES PATIENTS CONSIDÉRÉS POUR LE TRAITEMENT DE LA SURDITÉ PARTIELLE}

\section{Résumé}

Contexte: Létude présente l'utilisation des oto-émissions acoustiques (OAEs) pour évaluer l'audition de sujets touchés par la surdité partielle qui entendaient les fréquences jusquà $0,5 \mathrm{kHz}$, mais qui n’entendaient pas les fréquences plus élevées. Le but de cette étude était de détecter les oto-émissions acoustiques à $0,5 \mathrm{kHz}$ et de comprendre quels paramétres des oto-émissions acoustiques (gamme de fréquences large ou limitée) étaient les plus adaptés pour différencier les oreilles avec les oto-émissions acoustiques de celles sans OAE.

Matériel et méthodes: Le groupe d'étude était composé de 15 patients touchés par une perte auditive de hautes fréquences audessus de $0,5 \mathrm{kHz}$. Le groupe de référence était composé de 15 patients touchés par une perte auditive neurosensorielle sévère ou profonde sur la totalité de la gamme de 0,125 à $8 \mathrm{kHz}$. Dans les deux groupes, les oto-émissions acoustiques suscitées par large gamme de fréquences (CEOAEs) et les oto-émissions acoustiques évoquées par ton pur de courte durée (TBOAEs) de 1 ou $0,5 \mathrm{kHz}$ ont été évaluées en utilisant un paramètre de reproductibilité, en tenant compte des valeurs de la bande large, de l'octave, et de la bande demi-octave.

Résultats: Dans le groupe détude, les meilleurs résultats ont été obtenus en utilisant les oto-émissions acoustiques évoquées par ton pur de courte durée (TBOAEs) de $0,5 \mathrm{kHz}$. Les larges gammes de fréquences (clicks) et les impulsions sonores de 1 $\mathrm{kHz}$ nont généralement pas produit de réponse à $0,5 \mathrm{kHz}$. Les oto-émissions acoustiques évoquées par ton pur de courte durée (TBOAEs) à $0,5 \mathrm{kHz}$ ont permis de différencier les oreilles touchées par la surdité partielle - des oreilles touchées par une grave déficience auditive. Le filtrage de la bande demi-octave a donné les meilleurs résultats, mais il nétait que légèrement meilleur par rapport au filtrage de labande large et de la bande d’octave.

Conclusions: Les résultats de leétude indiquent que, quand il est nécessaire de tester la fonction cochléaire à basses fréquences, loto-émission acoustique évoquée par ton pur de courte durée (TBOAE) de $0,5 \mathrm{kHz}$ stimule mieux que l'otoémission acoustique suscitée par large gamme de fréquences (CEOAE) et que la TBOAE de $1 \mathrm{kHz}$. La bande de demi-octaves semble être le meilleur choix afin d’obtenir des informations sur lesfréquences spécifiques. Cependant,, les résultats doivent être traités avec prudence, car les groupes étudiés étaient relativement peu nombreux.

Mots clés: oto-émissions acoustiques • traitement de la surdité partielle • reproductibilité

\section{ПРИМЕНЕНИЕ ОТОАКУСТИЧЕСКОЙ ЭМИССИИ ДЛЯ ОЦЕНКИ СЛЫШИМОСТИ В НИЗКОЧАСТОТНОМ ДИАПАЗОНЕ У ПАЦИЕНТОВ, НАПРАВЛЕННЫХ НА ЛЕЧЕНИЕ ЧАСТИЧНОЙ ГЛУХОТЫ}

\section{Краткий обзор}

История вопроса: В настоящем исследовании применяли отоакустическую эмиссию (ОАЕ) для оценки слышимости у пациентов с частичной глухотой, у которых сохранялась слышимость в полосе до 0,5 кГц с выраженным ее снижением на более высоких частотах. Целью данного исследования являлось определение ОАЕ при 0,5 кГц и выяснение, какие именно значения - широкополосные или ограниченно-полосные - параметров ОАЕ более предпочтительны для определения органов слуха с ОАЕ и без таковых.

Материалы и методы: Опытная группа состояла из 15 пациентов с нарушениями слуха при высоких частотах свыше 0,5 кГц. В качестве контрольной группы выступали 15 пациентов с сенсоневральными нарушениями слуха 
со степенью выраженности от острой до глубокой по всему диапазону в пределах 0,125-8 кГц. В обеих группах проводили оценку ОАЕ с развитием по щелчку (CEОАЕ) и по тональному всплеску (ТВОАЕ) с частотой 1 или 0,5 кГц с применением параметра воспроизводимости, принимая во внимание широкополосные, октавные и полуоктавные частотные значения.

Результаты: В опытной группе наилучшие результаты были достигнуты при использовании ТВОАЕ с частотой 0,5 кГц. Щелчки и тональные всплески частотой 1 кГц, как правило, не приводили к ответу на частоте 0,5 кГц. TBOAЕ на частоте 0,5 кГц позволили установить различие между органами слуха с частичной глухотой и органами слуха с острыми нарушениями слуха. Фильтрование в полуоктавной полосе позволило получить наилучшие результаты; при этом такие результаты незначительно превышали результаты, полученные при широкополосном фильтровании и фильтровании в октавной полосе.

Заключение: Результаты исследования показали, что ТВОАЕ с частотой 0,5 кГц является лучшим стимулятором по сравнению с СЕОАЕ и ТВОАЕ с частотой 1 кГц в целях обследования кохлеарных функций при низких частотах. Полуоктавная полоса является наилучшим выбором для получения частотной информации. Тем не менее, результаты следует трактовать с осторожностью, поскольку опытные группы были относительно невелики.

Ключевые слова: отоакустическая эмиссия • лечение частичной глухоты • воспроизводимость ty

\section{Background}

Otoacoustic emissions (OAEs) were first described by Kemp [1] and are now well established in audiological practice (e.g. $[2,3]$ ). The most commonly used OAEs are click-evoked OAEs (CEOAEs) and distortion product OAEs (DPOAEs) evoked by two tonal stimuli. OAEs are believed to be good predictors of hearing status, particularly in the $1-4 \mathrm{kHz}$ range. However, while DPOAEs perform more satisfactorily at higher frequencies, CEOAEs are better indicators of cochlear function at lower frequencies [4].

Several studies have used OAEs in cases of high frequency hearing loss (e.g. [5-7]). The basal (high frequency) region of the cochlea is most prone to damage and this is reflected in OAEs. It has been shown that OAEs are absent in frequency bands having hearing loss and are present whenever hearing levels are better than $20 \mathrm{~dB}$ HL. It has also been observed that low- to mid-frequency OAEs are reduced in amplitude (compared to subjects with normal hearing) in frequency regions below those showing compromised hearing.

OAEs can also be evoked by tone bursts, which are short stimuli centered at a certain frequency. Several studies (e.g. $[8,9]$ ) have shown that the spectral content of a sum of tone burst-evoked OAEs (TBOAEs) centered on the $1-4 \mathrm{kHz}$ region corresponds to that in a CEOAE. It is nevertheless the case that for tone bursts, the same level of stimulus as the equivalent click gives a higher level of OAE (e.g. [10]). Therefore tone burst stimuli have an advantage over standard click stimuli in some difficult cases. It has been determined that use of $1 \mathrm{kHz}$ TBOAEs may reduce referral rates in screening outcomes [11] and $0.5 \mathrm{kHz}$ TBOAEs may provide an advantage over CEOAEs when searching for responses at frequencies lower than $1 \mathrm{kHz}$ [12-14].

In the present study the main interest was in subjects with a particular audiogram configuration: partial deafness subjects with normal hearing up to $0.5 \mathrm{kHz}$ and severe hearing loss above that frequency. CEOAEs and 1 and $0.5 \mathrm{kHz}$ TBOAEs seem to be the most promising OAE types for this application. DPOAEs seem to be the least useful OAE for studying partial deafness: they perform rather poorly at lower frequencies, especially at $0.5 \mathrm{kHz}$ where they are unable to distinguish hearing impaired from normal hearing ears [4].

The purpose of this study was to detect OAEs at $0.5 \mathrm{kHz}$ in partially deaf subjects and determine whether broadband or band-limited values of OAE parameters were better at distinguishing ears with OAEs from those without.

\section{Material and Methods}

\section{Subjects}

The subjects tested consisted of adults with partial deafness and those with impaired hearing (almost totally deaf). In detail, the two groups had:

- Severe to profound sensorineural hearing loss - 12 subjects ( 6 females, 6 males), 15 ears, age $46 \pm 5$ years. Hearing loss over all audiometric frequencies $(0.125-8 \mathrm{kHz})$. This group was formed from ears that did not exhibit OAEs and was used for purposes of reference.

- Partial deafness - 13 subjects (7 females, 6 males), 15 ears, age $32 \pm 4$ years. Normal hearing thresholds for frequencies up to $0.5 \mathrm{kHz}$ and severe sensorineural hearing loss above this frequency.

Average audiograms for all groups are given in Figure 1.

\section{Procedures}

OAEs were measured in a quiet environment using an ILO-96 system (Otodynamics Ltd, Hatfield, UK) running software version 5 . Standard click stimuli and 0.5 - and $1-\mathrm{kHz}$ tone bursts (average amplitude $80 \pm 3$ peak dB SPL, nonlinear averaging protocol) were used to evoke a total of $520 \mathrm{OAE}$ responses. The tone bursts were four cycles long with equal rise/fall times and no plateau. The early part of the response was windowed automatically by the system to minimize stimulus artifacts. The window was $0-2.5 \mathrm{~ms}$ for clicks, and $0-10$ and $0-5 \mathrm{~ms}$ for 0.5 - and $1-\mathrm{kHz}$ tone bursts, respectively. Recordings were made in two acquisition windows: the standard one ending at 


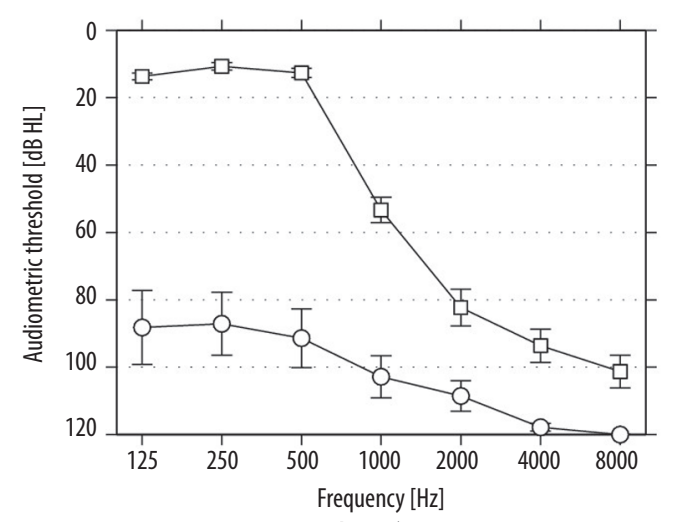

Figure 1. Average audiograms for the groups studied: partial deafness (squares), severe to profound sensorineural hearing loss (circles). Error bars indicate standard errors.

$20 \mathrm{~ms}$ for clicks and $1-\mathrm{kHz}$ tone bursts, and one ending at $30 \mathrm{~ms}$ for $0.5-\mathrm{kHz}$ tone bursts. The use of a $30 \mathrm{~ms}$ window for the $0.5 \mathrm{kHz}$ TBOAE was designed to accommodate emissions whose latency may often exceed that of the commonly used $20 \mathrm{~ms}$ window [13].
All OAE recordings were evaluated in terms of a reproducibility parameter. Estimates of this value were made for full-bandwidth and octave and half-octave bands (both at $0.5 \mathrm{kHz}$ ). Reproducibility was measured as the percentage correlation between two buffers of sub-averages [15].

Receiver operating characteristic (ROC) and area under the ROC curve (AUC) were used to gauge the efficiency with which OAEs can identify the presence or absence of hearing loss. An ROC curve plots the relative proportion of hits (sensitivity) against the number of false alarms (1 - specificity). Sensitivity is the likelihood of identifying an ear as impaired when hearing loss is present; specificity is the chance of identifying a normal hearing ear as normal; and efficiency is the proportion of ears that are correctly identified. AUC values range from 0.5 for a test with no diagnostic ability to 1.0 for a test with perfect diagnostic ability.

\section{Results}

In this study the OAE responses at $0.5 \mathrm{kHz}$ were of particular interest as $0.5 \mathrm{kHz}$ was the highest frequency at which hearing levels were in the normal range. In Figure 2 examples of reproducibility for CEOAEs and 1 and $0.5 \mathrm{kHz}$ TBOAEs are shown. This subject had hearing thresholds better than

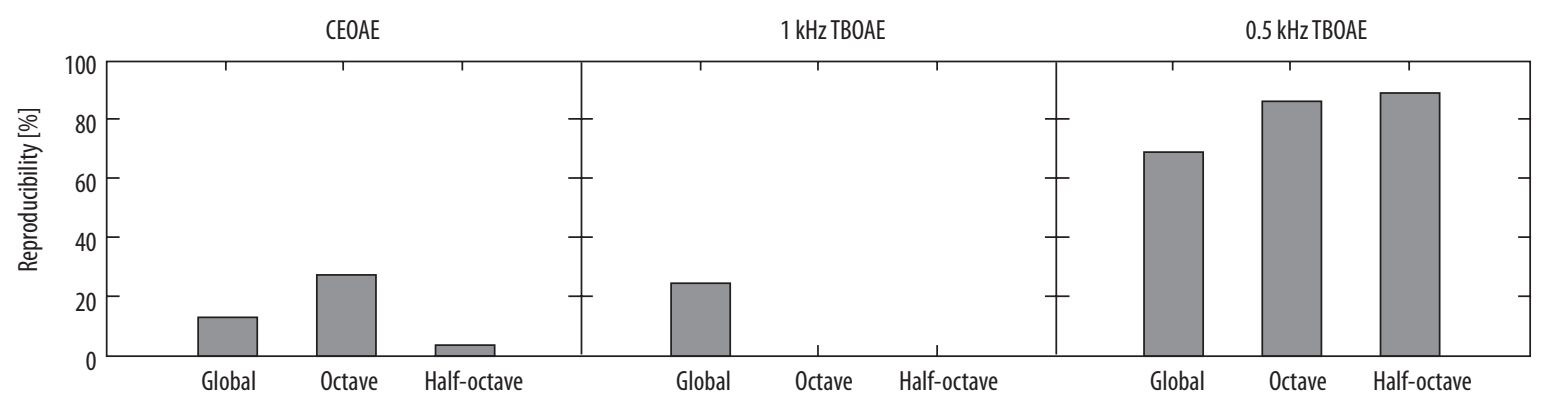

Figure 2. Examples of reproducibility values for CEOAE, and 1.0 and $0.5 \mathrm{kHz}$ TBOAEs, for a partial deafness subject (normal hearing for frequencies up to $0.5 \mathrm{kHz}$ and severe hearing loss above $0.5 \mathrm{kHz}$ ). Global values as well as octave and half-octave band values around $0.5 \mathrm{kHz}$ are shown.

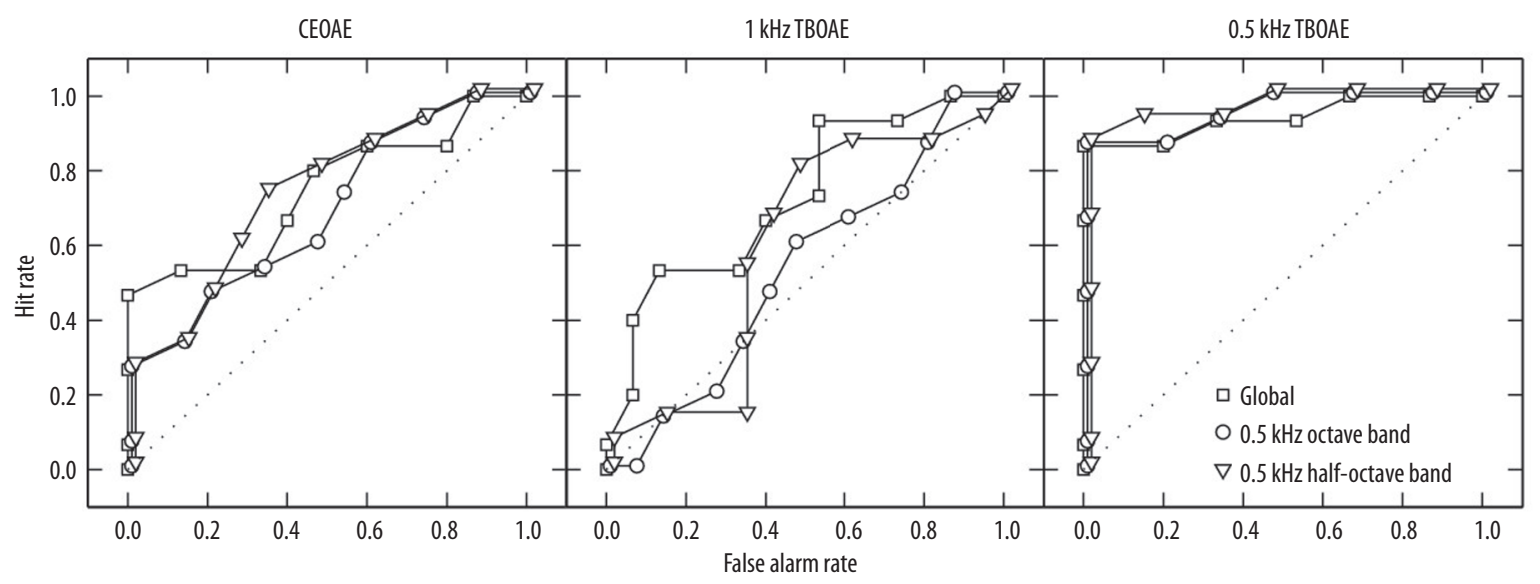

Figure 3. ROC curves for reproducibility for each type of OAE and for partial deafness patients with normal hearing up to $0.5 \mathrm{kHz}$. Calculations are based on global (broad-band) and octave and half-octave values around $0.5 \mathrm{kHz}$. 
Table 1. AUC values for Figure 3.

\begin{tabular}{|c|c|c|c|}
\hline & CEOAE & $\mathbf{1 ~ k H z ~ T B O A E}$ & $\mathbf{0 . 5} \mathbf{k H z}$ TBOAE \\
\hline Global & 0.73 & 0.73 & 0.94 \\
\hline $0.5 \mathrm{kHz}$ octave band & 0.69 & 0.54 & 0.96 \\
\hline $0.5 \mathrm{kHz}$ half-octave band & 0.74 & 0.60 & 0.97 \\
\hline
\end{tabular}

$20 \mathrm{~dB} \mathrm{HL}$ for frequencies up to $0.5 \mathrm{kHz}$ and higher than $50 \mathrm{~dB}$ HL in the remaining frequencies. The reproducibility values for broad-band (global) and octave and half-octave bands at $0.5 \mathrm{kHz}$ are shown. Values for higher frequencies were not taken into account as it was unlikely that the studied group exhibited OAEs in this range. It may be seen that reproducibility for CEAOEs and $1 \mathrm{kHz}$ TBOAEs did not exceed $50 \%$ (the smallest value for which one can consider presence of any response). On the other hand, $0.5 \mathrm{kHz}$ reproducibility was better than $60 \%$ for broad-band analysis and even higher than $80 \%$ for band-limited values.

ROC analysis was used to determine which type of stimuli best separates partially deaf subjects from totally deaf ones. ROC curves were calculated for the study group (i.e. partial deafness) versus the group with severe hearing impairment at all audiometric frequencies. The ROC curves for reproducibility are shown in Figure 3, with corresponding AUCs in Table 1.

The ROC analysis demonstrated that CEOAEs were not useful in differentiating the study group. Similar values of AUC (around 0.7) were obtained for all bands. The $1 \mathrm{kHz}$ TBOAE performed even slightly poorer. However this might be expected as it was studied for the $0.5 \mathrm{kHz}$ band, which is slightly off the stimulation value. Therefore it is not surprising that the best results for the $1 \mathrm{kHz}$ TBOAE were obtained for broad-band values. The $0.5 \mathrm{kHz}$ TBOAE enabled the best separation, with AUC $>0.9$ for all bands. The highest AUC values were obtained for the half-octave band.

\section{Discussion}

The purpose of this study was to evaluate OAEs as a tool for assessing the hearing status of patients considered for partial deafness treatment (PDT, as introduced by Skarzynski et al., $[16,17])$. It was found that CEOAEs and $1 \mathrm{kHz}$ TBOAEs are not good predictors of hearing status at 0.5 $\mathrm{kHz}$. On the other hand, $0.5 \mathrm{kHz}$ TBOAEs had high levels of reproducibility and enabled satisfactory separation of partially deaf ears from ears with severe to profound hearing loss at all audiometric frequencies.

The properties of OAE parameters such as reproducibility, response level, and signal to noise ratio in relation to different frequency bands have been investigated in several studies (e.g. $[4,12])$. Usually it was the case that CEOAEs were not efficient at $0.5 \mathrm{kHz}$. The same property was reproduced in the present study.
It might be expected that the $1 \mathrm{kHz}$ TBOAE would not be especially effective at $0.5 \mathrm{kHz}$. Nevertheless, since tone bursts stimulate quite broad regions of the cochlea it seemed important to prove this experimentally. It is therefore not surprising that for the $1 \mathrm{kHz}$ TBOAE the best results were achieved for broadband reproducibility rather than at bands centered at $0.5 \mathrm{kHz}$ (Table 1).

For the $0.5 \mathrm{kHz}$ TBOAE, analysis of the broad-band, octave, and half-octave band reproducibility parameter yielded similar results. However the half-octave band provided slightly better results than other two. The half-octave band seems the best choice in order to get frequency-specific information. Other authors also recommend use of half-octave bands in OAE analysis [12].

It should be pointed out that the ROC analysis used here differs from that used in most OAE studies. Usually this type of analysis is performed for a group of normally hearing ears and a group of ears with various levels of hearing impairment. In such an analysis, partially deaf subjects would be in the second group and their low-frequency hearing would be undetected. Therefore here the partially deaf ears were analyzed in comparison with ears that had broad-band severe hearing loss.

CEOAEs are absent in the majority of patients considered for cochlear implantation. This paper shows that the presence of a $0.5 \mathrm{kHz}$ TBOAE could be used as one test in the diagnostic procedure for PDT. The $0.5 \mathrm{kHz}$ TBOAE test could be particularly helpful when pure tone audiometry is not possible.

To conclude, the $0.5 \mathrm{kHz}$ TBOAE is more reliable than the CEOAE in the case of activity at low frequencies. The $0.5 \mathrm{kHz}$ TBOAE is a promising tool for the detection of emissions in patients with deep, high-frequency hearing loss when click stimuli do not produce OAEs. Nevertheless, the results should be treated with caution since the study groups were quite small.

\section{Acknowledgments}

Some initial results that led to present paper were presented at the Ninth European Symposium on Paediatric Cochlear Implantation, held in Warsaw, Poland, May 14-17, 2009, and may be found in the conference proceedings (Jedrzejczak et al., 2010 [14]). This research was partially funded by the Polish Ministry of Science and Higher Education. 


\section{References:}

1. Kemp DT: Stimulated acoustic emissions from within the human auditory system. J Acoust Soc Am, 1978; 64: 1386-91

2. Lonsbury-Martin BL, Whitehead ML, Martin GK: Clinical applications of otoacoustic emissions. J Speech Hear Res, 1991; 34: 964-81

3. Hatzopoulos S, Prosser S, Mazzoli M et al: Clinical applicability of transient evoked otoacoustic emissions: identification and classification of hearing loss. Audiol Neurootol, 1998; 3: 402-18

4. Gorga MP, Neely ST, Bergman BM et al: A comparison of transient-evoked and distortion product otoacoustic emissions in normal-hearing and hearing-impaired subjects. J Acoust Soc Am, 1993; 94: 2639-48

5. Attias J, Furst M, Furman V et al: Noise-induced otoacoustic emission loss with or without hearing loss. Ear Hear, 1995; 16: 612-18

6. Robinette MS: Clinical observations with evoked otoacoustic emissions at Mayo Clinic. J Am Acad Audiol, 2003; 14: 213-24

7. Konopka W, Pawlaczyk-Luszczynska M, Sliwinska-Kowalska $M$ et al: Effects of impulse noise on transiently evoked otoacoustic emission in soldiers. Int J Audiol, 2005; 44: 3-7

8. Elberling C, Parbo NJ, Johnsen NJ et al: Evoked acoustic emissions: clinical application. Acta Otolaryngol Suppl, 1985; 421: 77-85

9. Probst R, Coats AC, Martin GK et al: Spontaneous, click-, and toneburst-evoked otoacoustic emissions from normal ears. Hear Res, 1986; 21: 261-75
10. Prieve BA, Gorga MP, Neely ST: Click- and tone-burst-evoked otoacoustic emissions in normal-hearing and hearing-impaired ears. J Acoust Soc Am, 1996; 99: 3077-86

11. Zhang VW, McPherson B, Shi BX et al: Neonatal hearing screening: a combined click evoked and tone burst otoacoustic emission approach. Int J Pediatr Otorhinolaryngol, 2008; 72: 351-60

12. Lichtenstein V, Stapells DR: Frequency-specific identification of hearing loss using transient-evoked otoacoustic emissions to clicks and tones. Hear Res 1996; 98: 125-36

13. Jedrzejczak WW, Lorens A, Piotrowska A et al: Otoacoustic emissions evoked by $0.5 \mathrm{kHz}$ tone bursts. J Acoust Soc Am, 2009; 125: 3158-65

14. Jedrzejczak WW, Lorens A, Piotrowska A et al: The evaluation of patients with partial deafness by transiently evoked otoacoustic emissions. Cochlear Implants Int, 2010; 11(Suppl.1): 110-13

15. Kemp DT, Bray P, Alexander L, Brown AM: Acoustic emission cochleography - practical aspects. Scand Audiol Suppl, 1986; 25: 71-95

16. Skarzynski H, Lorens A, Piotrowska A: A new method of partial deafness treatment. Med Sci Monit, 2003; 9(4): CS20-24

17. Skarzynski H, Lorens A, Piotrowska A, Skarzynski PH: Hearing preservation in partial deafness treatment. Med Sci Monit, 2010; 16(11): CR555-62 